\title{
KLOROFIL LAMUN DAN KARAKTERISTIK PERAIRAN \\ PANTAI ALANG-ALANG, KARIMUNJAWA
}

\section{SEAGRASS CHLOROPHYLL AND CHARACTERISTICS ALANG-ALANG KARIMUNJAWA COSTAL}

\author{
Patria Theda Ramadanti ${ }^{1}$, Agus Hartoko ${ }^{2} \&$ Nurul Latifah $^{3}$ \\ ${ }^{1}$ Program Studi Manajemen Suumberdaya Perairan, \\ ${ }^{2}$ Departemen Sumberdaya Akuatik \\ ${ }^{3}$ Fakultas Perikanan dan Ilmu Kelautan, \\ ${ }^{4}$ Universitas Diponegoro \\ e-mail : patriatheda24@gmail.com
}

Diterima tanggal: 10 Juni 2020 ; diterima setelah perbaikan: 27 September 2020 ; Disetujui tanggal: 12 April 2021

\begin{abstract}
ABSTRAK
Pantai Alang-alang merupakan pemukiman di Pulau Karimunjawa yang memiliki padang lamun dengan kondisi masih baik. Lamun merupakan tumbuhan tingkat tinggi yang hidup terbenam di lingkungan laut; berpembuluh, berdaun, berimpang (rhizome), berakar dan berkembangbiak secara generatif(biji) dan vegetatif (tunas). Klorofil merupakan faktor utama yang mempengaruhi fotosintesis. Penelitian ini bertujuan untuk mengetahui nilai indeks keanekaraman, keseragaman dan dominasi lamun yang ada di perairan Pantai Alang-alang Karimunjawa, mengetahui kondisi perairan pantai sebagai tempat hidup lamun serta mengetahui kondisi lamun di perairan tersebut dengan menganalisis nilai klorofil lamun. Penelitian dilakukan pada Desember 2019 di perairan Pantai Alang-alang, Karimunjawa. Pengambilan sampel dilakukan pada 1 stasiun dengan 6 titik pengukuran garis transek dan 18 titik kuadran transek.Hasil dari penelitian ini yaitu nilai keanekaragaman berkisar antara 0,9561,215 dengan kategori keanekaragaman sedang. Nilai indeks keseragaman lamun berkisar antara 0,834-0,992 yang termasuk dalam kategori tinggi. Nilai indeks dominasi berkisar antara 0,330-0,436 yang dapat dikategorikan rendah. Kedalaman lokasi penelitian berkisar antara 24-68 meter. Temperatur air berkisar antara 26-32 ${ }^{\circ} \mathrm{C}$. Derajat keasaman $(\mathrm{pH})$ berkisar antara 7-8 dimana nilai tersebut masih dalam kondisi optimum. Salinitas bernilai 2830 o/oo. Nilai intensitas cahaya pada udara berkisar antara 1.200- 11.000 lux sedangkan untuk nilai intensitas cahaya pada permukaan air berkisar 1.100-9.600. Nilai klorofil pada lamun perairan diperairan tersebut berkisar antara $5.430-19.507 \mathrm{mg} / \mathrm{ml}$.
\end{abstract}

Kata kunci: Klorofil; kondisi perairan; lamun; Pantai Alang-alang.

\begin{abstract}
Alang-Alang Beach is a settlement on Karimunjawa Island which has seagrass in good condition. Seagrass is a higher plant that lives immersed in the marine environment; vascular, leafy, rhizome (rhizome), rooted and reproduce sexually (seeds) and vegetatively (shoots). Chlorophyll is the main factor affecting photosynthesis. This study aims to determine the value of the index of diversity, uniformity and dominance of seagrass in the waters of Alang-Alang Karimunjawa Beach, to determine the condition of coastal waters as a place for seagrass to live and to determine the condition of seagrass in these waters by analyzing the value of seagrass chlorophyll. The research was conducted in December 2019 in the waters of Alang-alang Beach, Karimunjawa. Sampling was conducted at 1 station with 6 transect line measurement points and 18 transect quadrant points. The results of this study were the diversity values ranged from 0.956 to 1.215 with moderate diversity categories. The seagrass uniformity index value ranges from 0.834-0.992 which is in the high category. The dominance index value ranges from 0.330-0.436 which can be categorized as low. The depth of the research location ranges from 24-68 meters. The water temperature ranges from $26-32^{\circ} \mathrm{C}$. The degree of acidity $(\mathrm{pH})$ ranges from 7-8 where this value is still in optimum conditions. Salinity is 28-30 o / oo. The value of light intensity in the air ranges from 1,200-11,000 lux, while the value of light intensity on the water surface ranges from 1,100-9,600. The chlorophyll value in seagrass in these waters ranges from 5,430-19,507 $\mathrm{mg} / \mathrm{ml}$.
\end{abstract}

Keywords: Chlorophyll; water conditions; seagrass; Alang-alang Coastal. 


\section{PENDAHULUAN}

Kepulauan Karimunjawa terletak di Laut Jawa yang termasuk dalam Kabupaten Jepara, Jawa Tengah, dengan luas wilayah daratan dan perairan 111.625 hektar, (Wicaksono \& Hartati, 2012). Pantai Alangalang merupakan salah satu pemukiman di Pulau Karimunjawa yang memiliki padang lamun yang kondisinya masih baik, (Ristina et al., 2018). Ekosistem padang lamun merupakan ekosistem yang cukup kompleks dengan segala fungsi yang penting terhadap ekosistem pesisir Ekosistem lamun juga memiliki peranan penting dalam ekosistem pesisir karena dapat membentuk padang rumput yang luas untuk mendukung keanekaragaman hayati yang tinggi (Traganos et al., 2018). Ekosistem lamun memiliki keterikatan dengan ekosistem disekitarnya, (Tangke, 2010). Pada umumnya ekosistem lamun terletak diantara ekosistem mangrove dan karang atau di dekat pantai berpasir (Rahmawati et al., 2014). Ekosistem lamun memberikan manfaat yang tidak sedikit bagi kesejahteraan masyarakat, berupa jasa ekosistem yang sangat bernilai dan dibutuhkan oleh manusia, baik secara ekologi, sosial, maupun secara ekonomi, (Wahyudin et al., 2016).

Lamun merupakan tumbuhan tingkat tinggi yang hidup dan terbenam di lingkungan laut; berpembuluh, berdaun, berimpang (rhizome), berakar dan berkembangbiak secara generatif (biji) dan vegetatif (tunas), (Sjafrie et al., 2018). Kualitas perairan yang dapat dilihat dari kedalaman, intensitas cahaya, $\mathrm{pH}$, salinitas serta temperatur air penting untuk diketahui. Kondisi lingkungan menjadi faktor yang berpengaruh terhadap kondisi dan persebaran lamun (Rahman et al., 2016).

Klorofil merupakan faktor utama yang mempengaruhi fotosintesis. Fotosintesis merupakan proses perubahan senyawa anorganik $\left(\mathrm{CO}_{2}\right.$ dan $\left.\mathrm{H}_{2} \mathrm{O}\right)$ menjadi senyawa organik (karbohidrat) dan $\mathrm{O} 2$ dengan bantuan cahaya matahari, (Ai \& Banyo, 2010).Klorofil adalah suatu pigmen yang memberi warna hijau pada tumbuhan hijau yang terdapat pada kloroplas. Klorofil menyerap cahaya berupa radiasi elektromagnetik. Korofil banyak menyerap sinar dengan panjang gelombang antara 400-700 nm, terutama sinar merah dan biru, (Gibson et al., 2017).

Penelitian ini bertujuan untuk mengetahui klorofil a pada lamun dan mengetahui karakteristik habitat lamun di perairan Pantai Alang-alang, Karimunjawa.

\section{BAHAN DAN METODE}

Penelitian dilakukan pada bulan Desember 2019 di perairan Pantai Alang-alang, Karimunjawa.Penentuan titik pengambilan data lapangan dilakukan dengan cara purposive sampling. Pengambilan sampel dilakukan pada 1 stasiun dengan 6 titik pengukuran garis transek dan 18 titik kuadran transek.

Pada saat di lapangan dilakukan pengambilan sampel lamun yang dominan pada setiap titik penelitian, dikemudian sampel lamun tersebut dimasukkan kedalam coolbox yang selalu diberi es batu. Sampel tersebut di analisis nilai klorofil dengan metode spektofotometri (Rosang \& Wagey, 2016). Uji klorofil tersebut dilakukan di Laboratorium Pengelolaan Sumberdaya Ikandan Lingkungan Departemen Sumberdaya Akuatik, FPIK, Universitas Diponegoro.

\section{Karakteristik Perairan Pantai Alang-alang, Karimunjawa}

Indeks Keanekaragaman, Keseragaman dan Dominasi

Analisis data dilakukan menggunakan indeks keanekaragaman, keseragaman dan dominasi dapat ditentukan dengan menggunakan teori informasi Shannon-Wienner. Keanekaragaman ditentukan berdasarkan indeks keanekaragaman Shannon-Wiener (Krebs, 1978)dengan rumus :

$$
H^{\prime}=-\sum_{t=1}^{s} p i \ln p i
$$

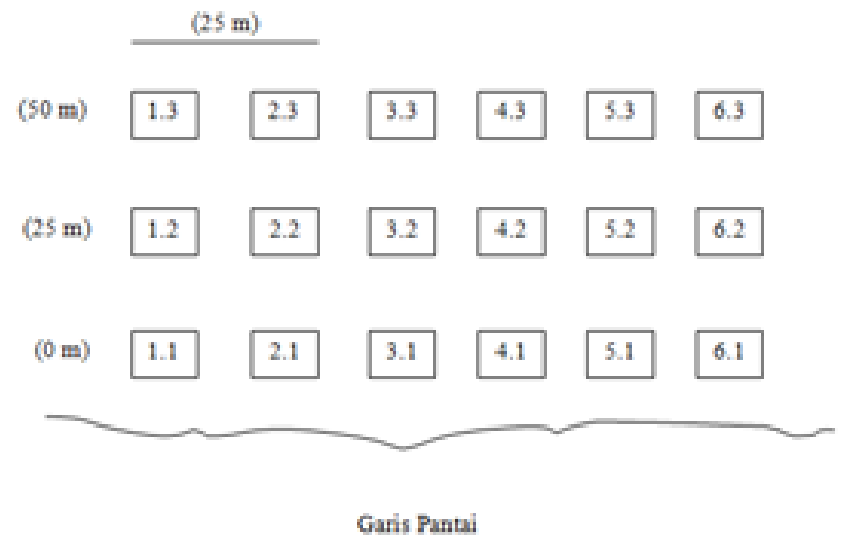

Gambar 1. Cara peletakan garis tansek dan kuadran transek. Figure 1. How to lay the transect line and quadrant transect. 


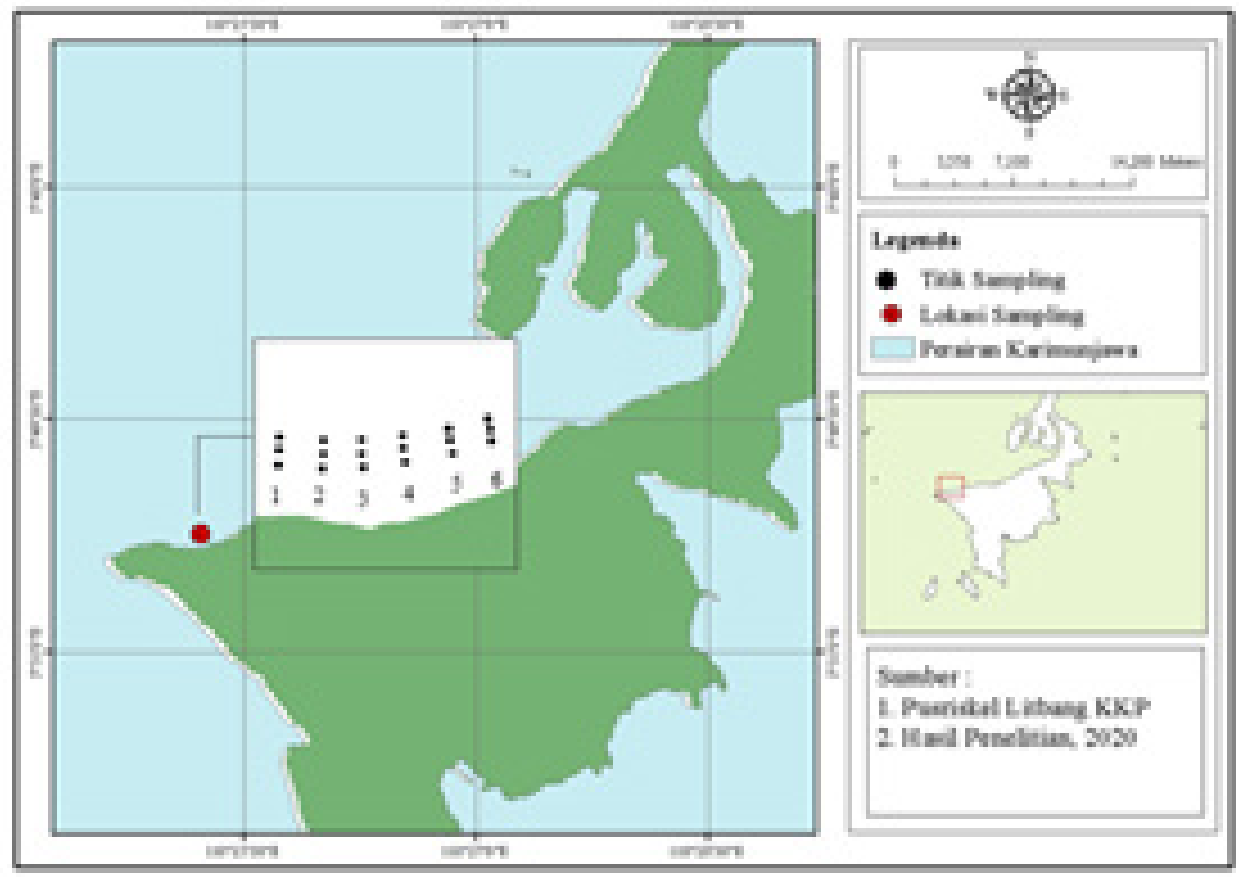

Gambar 2. Peta Lokasi Penelitian.

Figure 2. Map of Research Location.

dimana,

$\mathrm{H}^{\prime}=$ indeks keanekaragamanShannonWienner

$\mathrm{pi}=\mathrm{ni} / \mathrm{N}$

$\mathrm{ni}=$ Jumlah induvidu jenis ke- $\mathrm{i}$

$\mathrm{N}=$ Jumlah total induvidu

$\mathrm{S}=$ Jumlah genera/spesies

Dengan nilai :

Nilai H'> 3 keanekaragaman spesies tinggi

Nilai H' $1 \leq \mathrm{H}^{\prime} \leq 3$ keanekaragaman spesies sedang

Nilai $\mathrm{H}^{\prime}<1$ keanekaragaman spesies rendah

Untuk mengetahui seberapa besarkesamaan penyebaran jumlah individu digunakan indeks keseragaman, yaitu dengan (Odum, 1998):

$$
E=\frac{H}{H^{\prime} m a k s}
$$

dimana,

$\mathrm{E}=$ Indek keseragaman

$\mathrm{H}^{\prime}$ = Indeks keanekaragaman

$\mathrm{H}^{\prime}$ maks = Indeks keanekaragaman maksimum $(\ln \mathrm{S}$, dimana $\mathrm{S}$ adalah jumlah jenis) Indeks keseragaman berkisar antara $0-1$.

Untuk mengetahui adanya dominasi jenis tertentu di perairan dapat digunakan indeks dominasi (Odum, 1998):

$$
D=\sum_{t=1}^{s}\left(\frac{n i}{N}\right)
$$

dimana,

$\mathrm{D}=$ Indeks Dominasi

$\mathrm{N}=$ Total jumlah individu dalam sampel

$\mathrm{ni}=$ Jumlah individu spesies $\mathrm{i}$

\section{Kualitas Perairan}

Pengukuran kualitas perairan dilakukan langsung di lapangan. Pada penelitian kali ini dilakukan pengukuran kedalaman, intensitas cahaya, temperatur air, $\mathrm{pH}$ dan salinitas. Pengukuran tersebut dilakukan pada setiap titik kuadran transek penelitian dimana pada penelitian ini terdapat 18 titik.

\section{Kedalaman}

Alat yang digunakan yaitu meteran jahit, yang dimasukan ke dalam perairan dengan posisi terbaik. Perhatikan skala pada meteran jahit kemudian catat dengan satuan centimeter $(\mathrm{cm})$.

\section{Intensitas cahaya}

Alat yang digunakan yaitu lux meter. Cara pengukurannya dengan mengarahkan sensor cahaya pada permukaan daerah yang akan diukur intensitas cahayanya. Kemudian perhatikan hasil pengukuran pada layar panel. 


\section{Temperatur air}

Alat yang digunakan yaitu thermometer air raksa. Cara pengukurannya masukan thermometer ke dalam perairan, tunggu \pm 5 menit.

\section{$p H$}

Alat yang digunakan yaitu $\mathrm{pH}$ meter. Pengukuran dilakukan dengan mencelupkan $\mathrm{pH}$ meter ke dalam perairan selama \pm 2 menit. Kemudian lihat skala pada layar.e)

\section{Salinitas}

Alat yang digunakan dalam pengukuran salinitas yaitu refraktometer. Cara penggunaan alat refraktometer yaitu :

1. Kalibrasi refraktometer menggunakan aqudes

2. Sebanyak 2 tetes air sampel diteteskan pada prisma, kemudian arahkan pada matahari dan lihat angka yang tertera pada "eye piece". Kalibrasi kembali refraktometer menggunakan aquades.

\section{Klorofil Lamun}

Metode perhitungan klorofil pada lamun dimulai dengan menimbang sampel, kemudian dihaluskan lalu ditambahkan aseton sampai sampel terlarut dalam aseton. Kemudian disimpan dalam feezer selama 24 jam. Kemudian dipisahkan antara padatan dan cairan, kemudian menurut (Rosang \& Wagey, 2016) cairan dianalisis menggunakan spektofotometri untuk menentukan kandungan klorofil.

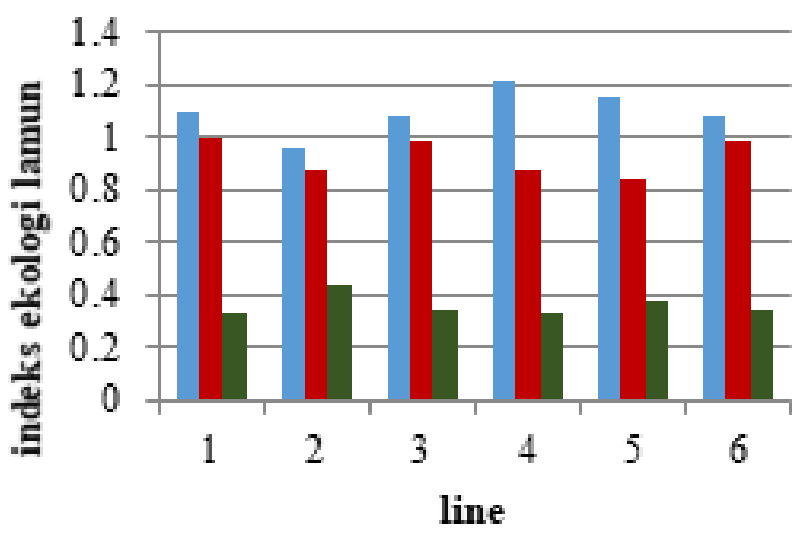

$\square$ Keanekaragaman $\boldsymbol{\nabla}$ Keseragaman Dom inasi

Gambar 3. Nilai indeks ekologi lamun. Figure 3. Seagrass ecological index values.

\section{HASIL DAN PEMBAHASAN}

\section{Karakteristik Perairan}

Indeks ekologi lamun

Nilai indeks ekologi lamun digunakan untuk melihat keseimbangan ekosistem lamun pada perairan Pantai Alang-alang, Karimunjawa. Nilai indeks ekologi lamun meliputi keanekaragaman, keseragaman dan dominasi.

Nilai indeks ekologi lamun digunakan untuk melihat keseimbangan ekosistem lamun pada perairan Pantai Alang-alang, Karimunjawa. Nilai indeks ekologi lamun meliputi keanekaragaman, keseragaman dan dominasi. Nilai indeks keanekaragaman lamun pada lokasi penelitian berkisar antara 0,956-1,215. Nilai hasil penelitian yang di kategorikan rendah yaitu pada line 2, untuk line 1,3,4,5 dan 6 dikategorikan memiliki keanekaragaman sedang. Menurut (Sugianti \& Mujiyanto, 2015) bahwa nilai keanekaragaman akan meningkat apabila jumlah jenis yang ditemukan semakin banyak, serta proporsi masing-masing jenis semakin merata.

Nilai indeks keseragaman lamun pada lokasi penelitian berkisar antara 0,834-0,992 yang termasuk dalam kategori tinggi. Nilai keseragaman tertinggi ada pada line 3 dan terendah ada pada line 5, namun nilai keseragaman pada line 1 sampai 6 dapat dikategorikan memiliki nilai keseragaman tinggi. Menurut (Sugianti \& Mujiyanto, 2015) bahwa nilai indeks keseragaman menunjukan bahwa rendahnya nilai penyebaran lamun yang artinya terdapat spesies yang mendominasi. Hal ini dapat disebabkan karena adanya perubahan kualitas perairan sehingga hanya beberapa jenis lamun yang dapat beradaptasi di lokasi tersebut.

Nilai indeks dominasi lamun pada lokasi penelitian berkisar antara 0,330-0,436 yang dapat dikategorikan rendah. Nilai dominasi tertinggi ada pada line 2 sedangkan nilai dominasi terendah ada pada line 4, namun nilai dominasi pada line 1 sampai 6 dikategorikan rendah.Menurut (Hoek et al., 2013) apabila nilai dominasi bernilai 1 atau lebih spesies pada suatu komunitas, maka biasanya diikuti nilai keseragaman yang kecil.

\section{Parameter kualitas perairan}

Parameter kualitas perairan yang diukur di lapangan yaitu kedalaman, temperature air, $\mathrm{pH}$, salinitas dan intensitas cahaya.

Berdasarkan hasil pengukuran yang dilakukan kedalaman lokasi penelitian berkisar antara 24- 
Tabel 1. Nilai parameter kualitas air

Table 1. Value of water quality parameters

\begin{tabular}{|c|c|c|c|c|c|c|}
\hline \multirow[t]{2}{*}{ Titik } & \multirow[t]{2}{*}{ Kedalaman (m) } & \multirow[t]{2}{*}{ Temperatur Air $\left({ }^{\circ} \mathrm{C}\right)$} & \multirow[t]{2}{*}{$\mathbf{p H}$} & \multirow[t]{2}{*}{ Salinitas (o/oo) } & \multicolumn{2}{|c|}{ Intensitas Cahaya (Lux) } \\
\hline & & & & & Udara & Permukaan air \\
\hline 1.1 & 0,45 & 26 & 7,82 & 29 & 144300 & 129870 \\
\hline 1.2 & 0,47 & 27 & 7,83 & 29 & 161300 & 145170 \\
\hline 1.3 & 0,52 & 26 & 7,81 & 29 & 186500 & 167850 \\
\hline 2.1 & 0,24 & 29 & 7,83 & 28 & 182300 & 164070 \\
\hline 2.2 & 0,37 & 29 & 7,83 & 28 & 105800 & 95220 \\
\hline 2.3 & 0,33 & 29 & 7,82 & 28 & 71700 & 64530 \\
\hline 3.1 & 0,27 & 29 & 7,82 & 28 & 81600 & 73440 \\
\hline 3.2 & 0,49 & 29 & 7,82 & 28 & 153000 & 137700 \\
\hline 3.3 & 0,62 & 30 & 7,82 & 28 & 160200 & 144180 \\
\hline 4.1 & 0,50 & 30 & 7,81 & 28 & 159000 & 143100 \\
\hline 4.2 & 0,57 & 30 & 7,81 & 28 & 60300 & 54270 \\
\hline 4.3 & 0,59 & 30 & 7,81 & 28 & 63800 & 57420 \\
\hline 5.1 & 0,57 & 31 & 7,72 & 29 & 256000 & 230400 \\
\hline 5.2 & 0,62 & 31 & 7,72 & 29 & 205730 & 185157 \\
\hline 5.3 & 0,65 & 31 & 7,72 & 29 & 43600 & 39240 \\
\hline 6.1 & 0,58 & 32 & 7,94 & 30 & 231200 & 208080 \\
\hline 6.2 & 0,65 & 32 & 7,94 & 30 & 241100 & 216990 \\
\hline 6.3 & 0,68 & 31 & 7,94 & 30 & 141000 & 126900 \\
\hline \multicolumn{2}{|c|}{ Nilai optimum } & $28-33^{\circ} \mathrm{C}$ & $6-8,5$ & $29-34$ o/oo & & \\
\hline
\end{tabular}

68 meter. Lokasi terdalam terdapat pada titik 6.3 kemampuan lamun untuk melakukan fotosintesis sedangkan lokasi terdangkal terdapat pada titik 2.1. akan menurun. Derajat keasaman (pH) pada lokasi Kedalaman merupakan faktor yang paling berpengaruh terhadap pertumbuhan lamun darena kedalaman air akan berpengaruh terhadap kecerahan yang dibutuhkan lamun untuk berfotosintesis, (Christon et al., 2012). Temperatur air pada lokasi penelitian berkisar antara $26-32^{\circ} \mathrm{C}$. Menurut (Sakey et al., 2015) Temperatur memiliki pengaruh yang sangat besar terhadap pertumbuhan lamun karena bermanfaat untuk proses fotosintesis, (Minerva et al., 2014) namun apabila temperatur tidak dalam kisaran 25-35oC maka penelitian berkisar antara 7-8 dimana nilai rentan tersebut masih dalam kondisi optimum. Nilai $\mathrm{pH}$ pada suatu perairan mempengaruhi biota suatu perairan. Menurut (Megawati et al., 2014) nilai pH perairan juga mempengaruhi kandungan nutrien atau produktivitas primer pada perairan tersebut. Salinitas pada lokasi penelitian bernilai $28-30$ o/oo. Nilai intensitas cahaya pada udara berkisar antara 1.200-11.000 lux sedangkan untuk nilai intensitas cahaya pada permukaan air berkisar 1.100-9.600 lux. Menurut (Widiadmoko,

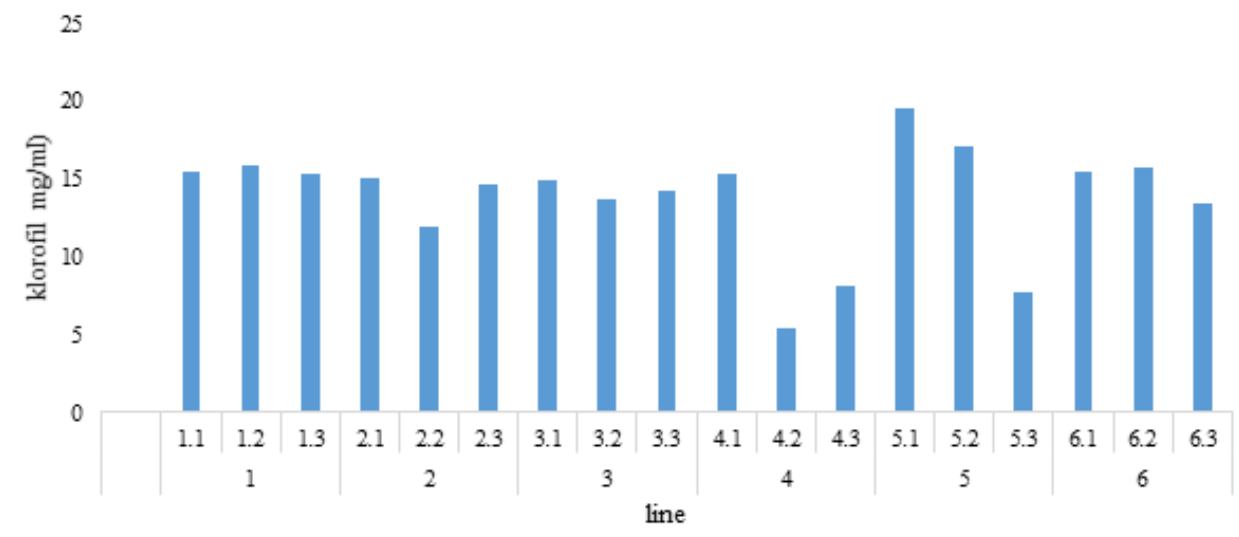

Gambar 4. Nilai klorofil lamun.

Figure 4. Seagrass chlorophyll values. 
2013) kemampuan cahaya matahari untuk menembus dasar peairan dipengaruhi oleh kekeurahan air. Oleh karena itu kecerahan dan kekeruhan air mempengaruhi pertumbuhan biota perairan tersebut yang hubungannya dengan proses fotosintesis yang membutuhkan cahaya matahari. Hasil penelitian kali ini tidak berbeda jauh dengan penelitian sebelumnya yang dilakukan oleh Ganefiani et al., 2019 pada perairan Karimunjawa bulan Maret 2018 yang memiliki kisaran suhu 28$30^{\circ} \mathrm{C}$ pada kedalaman 0,25-0,54 meter sehingga sinar matahari masih dapat menembus dasar perairan. Menurut (Sakey et al., 2015) kisaran nilai kualitas perairan tersebut tergolong baik untuk pertumbuhan lamun biota disekitarnya.

Menurut (Prayitno \& Afdal, 2019) kelarutan $\mathrm{CO}_{2}$ bebas dalam air laut ini dimanfaatkan untuk aktifitas proses fotosintesis oleh makhluk hidup perairan. Biomassa dalam ekosistem lamun dapat berperan sebagai penyimpan karbon dioksida dari atmosfer. Hal ini dapat dilihat bahwa tingginya nilai $\mathrm{pH}$ pada line 6 diikuti dengan tingginya nilai salinitas pada perairan tersebut.

\section{Nilai Klorofil Lamun}

Nilai klorofil pada lamun perairan Pantai Alang-alang, Karimunjawa berkisar antara 5.430-19.507 mg/l. Klorofil tertinggi ada pada titik 5.1 yaitu sebesar 19.507 $\mathrm{mg} / \mathrm{l}$ dengan spesies yang mendominasi Cymodocea rotundata. Sedangkan klorofil terendah ditemukan pada titik 4.2 dengan spesies yang mendominasi yaitu Enhalus acoroides.

Nilai klorofil lamun memiliki keterkaitan dengan salinitas dan temperatur perairan. Perairan yang memiliki nilai salinitas dan temperatur yang optimum diikuti dengan intensitas cahaya yang optimum menjadikan perairan tersebut menjadi subur karena tumbuhan air termasuk lamun dapat berfotosintesis secara baik. Hal tesebut dijelaskan (Ridho et al., 2018) oleh kecerahan perairan sangat berhubungan dengan kesuburan perairan yaitu berlangsungnya proses fotosintesis oleh lamun, sehingga menunjang peranannyasebagai produsenprimerdiperairan.Apabila perairan subur maka banyak biota yang berhabitat pada ekosistem tersebut sehingga pada ekosistem tersebut banyak terdapat karbon inorganik yang nantinya akan tersimpan dalam biomassa lamun tersebut. Menurut (Agustin et al., 2014) bahwa kemampuan lamun dalam berfotosintesis memanfaatkan $\mathrm{CO}_{2}$ dan menyimpannya dalam biomassa atau dikenal dengan istilah blue carbon. Kandungan klorofil lamun yang rendah dapat menurunkan populasi lamun pada ekosistem tersebut, hal ini karena terganggunya proses fotosintesis lamun, (Natsir et al., 2020)

\section{KESIMPULAN DAN SARAN}

Kesimpulan dari penelitian Klorofil Lamun dan Karakteristik Perairan Pantai Alang-alang, Karimunjawa adalah :

1. Nilai keanekaragaman pada perairan Pantai Alangalang berkisar antara 0,956-1,215 dengan kategori keanekaragaman sedang. Nilai indeks keseragaman lamun pada lokasi penelitian berkisar antara 0,8340,992 yang termasuk dalam kategori tinggi.Nilai indeks dominasi lamun pada lokasi penelitian berkisar antara 0,330-0,436 yang dapat dikategorikan rendah.

2. Kedalaman lokasi penelitian berkisar antara 24-68 meter.Temperatur air pada lokasi penelitian berkisar antara $26-32^{\circ} \mathrm{C}$. Derajat keasaman $(\mathrm{pH})$ pada lokasi penelitian berkisar antara 7-8 dimana nilai rentan tersebut masih dalam kondisi optimum. Salinitas pada lokasi penelitian bernilai 28-30 o/oo. Nilai intensitas cahaya pada udara berkisar antara 1.200- 11.000 lux sedangkan untuk nilai intensitas cahaya pada permukaan air berkisar 1.100-9.600.

3. Nilai klorofil pada lamun perairan Pantai Alangalang, Karimunjawa berkisar antara 5.430-19.507 mg/1.

\section{UCAPAN TERIMA KASIH}

Penulis mengucapkan terimakasih kepada Pemberi dana penelitian yaitu Lembaga Penelitian dan Pengabdian Masyarakat (LPPM) Universitas Diponegoro, selain APBN DPA LPPM Universitas Diponegoro Tahun 2019 dengan Nomor SPK 385-31/UN7.P4.3/PP/2019, Lembaga Balai Taman Nasional Karimunjawa yang telah membantu dan memberikan izin sehingga artikel ini dapat diselesaikan. Serta terimakasih kepada berbagai pihak yang telah membantu dalam penyelesaian artikel ini.

\section{DAFTAR PUSTAKA}

Agustin, R., Kepel, T. L., Afiati, R. N., Salim, H. L., Astrid, M., Daulat, A., Mangindaan, P., Sudirman, N., Rahayu, Y. P., Suryono, D. D., \& Hutahaenan, A. (2014). Peran Ekosistem Lamun Sebagai Blue Carbon Dalam Mitigasi Perubahan Iklim, Studi Kasus Tanjung Lesung, Banten. Jurnal Segara, 10(2), 107-117.

Ai, N. S., \& Banyo, Y. (2010). Konsentrasi Klorofil Daun Sebagai Indikator Kekurangan Air Pada

JURNAL KELAUTAN NASIONAL, Vol. 16, No 1, April 2021, Hal. 25-32 
Tanaman. Ilmiah Sains, 11(2), 166-173.

Christon., Djunaedi, O., \& Purba, N. (2012). Pengaruh Tinggi Pasang Surut Terhadap Pertumbuhan Dan Biomassa Daun Lamun Enhalus Acoroides Di Pulau Pari Kepulauan Seribu Jakarta. Jurnal Perikanan Dan Kelautan, 3(3), 287-294.

Ganefiani, A., Suryanti, S., \& Latifah, N. (2019). Potensi Padang Lamun Sebagai Penyerap Karbon Di Perairan Pulau Karimunjawa, Taman Nasional Karimunjawa. Saintek Perikanan: Indonesian Journal of Fisheries Science And Technology, 14(2), 115-122. Https://Doi. Org/10.14710/Ijfst.14.2.115-122

Gibson, M., Kasman., \& Iqbal. (2017). Analisa Kualitas Klorofil Daun Jarak Kepyar ( Ricinus Comunis L ) Sebagai Bahan Pewarna Pada Dye Sensitized Solar Cell ( Dssc ). Gravitasi, 16(2), 31-40.

Hoek, F., Gofir, A., \& Arhandy Arfah. (2013). Estimasi Indeks Keragaman Ikan Karang Di Daerah Perlindungan Laut (DPL) Kabupaten Raja Ampat - Papua Barat. Jurnal Airaha, 3(1), 2534.

Krebs, C. J. (1978). Ecology : The Experimental Analysis Of Distribution And Abundance. Harper \& Row. University of British Columbia, Vancouver.

Megawati, C., Yusuf, M., \& Maslukah, L. (2014). Sebaran Kualitas Perairan Ditinjau Dari Zat Hara, Oksigen Terlarut Dan Ph Di Perairan Selat Bali Bagian Selatan. Journal of Oceanography, 3(2), 142-150.

Minerva, A., Purwanti, F., \& Suryanto, A. (2014). Analisis Hubungan Keberadaan Dan Kelimpahan Lamun Dengan Kualitas Air Di Pulau Karimunjawa, Jepara. Diponegoro Journal Of Maquares, 3(3), 88-94.

Natsir, N. A., Selanno, D. A. ., \& Tupan, Charlotha.I., Y. T. M. (2020). Analisis Kandungan Merkuri (Hg) Dan Kadar Klorofil Lamun Enhalus Acoroides Di Perairan Marlosso Dan Nametek Kabupaten Buru Provinsi Maluku Nur. Jurnal Biology Science \& Education, 9(1), 89-100.

Odum, E. P. (1998). Dasar-Dasar Ekologi. 3rd Ed. Gadja Mada.
Prayitno, H. B., \& Afdal. (2019). Sebaran Spasial Zat Hara Dan Klorofil-A: Potensi Fosfor Sebagai Faktor Penentu Eutrofikasi Di Teluk Jakarta. Jurnal Ilmu Dan Teknologi Kelautan Tropis, 11(1), 1-12.

Rahman, A., Nur, A., \& Ramli, M. (2016). Studi Laju Pertumbuhan Lamun (Enhalus Acoroides) Di Perairan Pantai Desa Tanjung Tiram Kabupaten Konawe Selatan. Jurnal Sapa Laut (Jurnal Ilmu Kelautan), 1(1), 10-16.

Rahmawati, S., Irawan, A., Supriyadi, I. H., \& Azkab, M. H. (2014). Panduan Monitoring Padang Lamun (Issue 1).

Ridho, M. G., Supriharyono, \& Rahman, A. (2018). Analisis Hubungan Jarak Dan Kedalaman Dengan Struktur Komunitas Lamun Di Pantai Pancuran, Kepulauan Karimunjawa. Journal Of Maquares, 7(4), 352-360. Https://Doi. Org/10.1017/Cbo9781107415324.004

Ristina, M., Sulardiono, B., \& Solichin, A. (2018). Hubungan Kerapatan Lamun (Seagrass) Dengan Kelimpahan Teripang (Holothuria) Di Pantai Alang-Alang Taman Nasional Karimunjawa. Journal Of Maquares, 7(4), 452-457. Https:// Doi.Org/10.1017/Cbo9781107415324.004

Rosang, C. I., \& Wagey, B. T. (2016). Penentuan Kandungan Pigmen Klorofil Pada Lamun Jenis Halophila Ovalis Di Perairan Malalayang. Jurnal Pesisir Dan Laut Tropis, 1(1), 15-19.

Sakey, W. F., Wagey, B. T., \& Gerung, G. S. (2015). Variasi Morfometrik Pada Beberapa Lamun Di Perairan Semenanjung Minahasa. Jurnal Pesisir Dan Laut Tropis, 3(1), 1. Https://Doi. Org/10.35800/Jplt.3.1.2015.7724

Sjafrie, N. D. M., Hernawan, U. E., Prayudha, B., Supriyadi, I. H., Iswari, M. Y., Rahmat, Anggraini, K., \& Suyarso. (2018). Status Padang Lamun Indoenesia 2018. Www.Oseanografi. Lipi.Go.Id.

Sugianti, Y., \& Mujiyanto. (2015). Evaluasi Kesuburan Ekosistem Padang Lamun Dengan Menggunakan Bioindikator Fitoplankton Di Pulau Karimunjawa, Jawa Tengah. Jurnal Teknologi Lingkungan, 16(1), 9-14. Https://Doi. Org/10.1017/Cbo9781107415324.004 
Tangke, U. (2010). Ekosistem Padang Lamun. Ilmiah Agribisnis Dan Perikanan (Agrikan UmmuTernate), 3(1), 9-29.

Traganos, D., Aggarwal, B., Poursanidis, D., Topouzelis, K., Chrysoulakis, N., \& Peter Reinartz. (2018). Towards Global-Scale Seagrass Mapping And Monitoring Using Sentinel-2 On Google Earth Engine: The Case Study Of The Aegean And Ionian Seas. J. Mdpi, 10(8), 1227.

Wahyudin, Y., Kusumastanto, T., Adrianto, L., \& Yusli Wardiatno. (2016). Jasa Ekosistem Lamun Bagi Kesejahteraan Manusia Yudi. Omni-Akuatika, 12(3), 29-46. https://Doi.Org/10.5151/ Cidi2017-060

Wicaksono, S. G., \& Hartati, S. T. (2012). Struktur Vegetasi Dan Kerapatan Jenis Lamun Di Perairan Kepulauan Karimunjawa Kabupaten Jepara. Journal Of Marine Research, 1(2), 1-7.

Widiadmoko, W. (2013). Pemantauan Kualitas Air Secara Fisika Dan Kimia Di Perairan Teluk Hurun. Balai Besar Pengembangan Budidaya Laut (BBPBL) Lampung. 